\title{
A New Chalcone from Propolis Collected on Jeju Island, Korea
}

\author{
Shigenori Kumazawa ${ }^{1 *}$, Shou Suzuki ${ }^{1}$, Mok-Ryeon Ahn ${ }^{1}$, Miya Kaminira ${ }^{1}$, Yu Udagawa ${ }^{1}$, \\ Keuk-Seung BANG ${ }^{2}$ and Tsutomu NAKAYAMA ${ }^{1}$ \\ ${ }^{1}$ Laboratory of Functional Food Science and COE Program in the 21st Century, School of Food and Nutritional Sciences, University \\ of Shizuoka, 52-1 Yada, Suruga-ku, Shizuoka 422-8526, Japan \\ ${ }^{2}$ Department of Food Science, Dong-A University, 840 Hadan 2-dong, Saha-gu, Busan 604-714, Korea
}

Received November 4, 2005; Accepted February 16, 2006

The new chalcone, 4'-methoxy-bavachromanol (1), was isolated from propolis collected on Jeju, a southern island of Korea together with two known compounds, laserpitin (2) and isolaserpitin (3). The structure of each compound was determined by spectral methods, including mass spectrometry and 2D NMR. The $\mathrm{IC}_{50}$ value of 1 against soybean lipoxygenase was $14.6 \mu \mathrm{M}$.

Keywords: propolis, Jeju, chalcone, khellactone, 4'-methoxy-bavachromanol, lipoxygenase

\section{Introduction}

Propolis, a natural substance collected by honeybees from buds and exudates of certain trees and plants to protect their beehives from enemies, is used in folk medicine in many regions of the world and has been reported to have various biological activities such as antibacterial (Kujumgiev et al., 1999), antiviral (Amoros et al., 1994), anti-inflammatory (Wang et al., 1993), and anticancer (Kimoto et al., 2001) properties. Propolis is extensively used in food and beverages to promote health and prevent diseases such as inflammation, heart disease, diabetes, and cancer (Burdock, 1998).

Propolis usually contains a variety of chemical compounds such as polyphenols (flavonoids, phenolic acids and their esters), terpenoids, steroids, and amino acids. The composition of propolis depends upon the vegetation at the site of collection. Due to the geographical difference, propolis samples from Europe, South America, and Asia have different chemical compositions (Marcucci, 1995; Tazawa et al., 2000; Kumazawa et al., 2004). Propolis from Europe and China contained many kinds of flavonoids and phenolic acid esters (Bankova et al., 2000). In contrast, the major components in propolis of Brazilian origin were terpenoids and prenylated derivatives of $p$ coumaric acids (Marcucci \& Bankova, 1999; Tazawa et al., 1999; Kumazawa et al., 2003). However, the detailed components of Korean propolis have not been reported. Therefore, we have studied the components in Korean propolis from different geographic origins (Ahn et al., 2004) and found that propolis from Jeju island has constituents not present in propolis from other regions. Jeju is a southern island of Korea with a subtropical climate.

* To whom correspondence should be addressed.

E-mail: kumazawa@smail.u-shizuoka-ken.ac.jp
We examined the components in propolis collected on Jeju island, and isolated three of these components (1-3) (Fig. 1). Here we describe the structure and soybean lipoxygenase inhibition activity of these compounds.

\section{Materials and Methods}

General Experimental Procedure Melting point (mp) data, recorded with a Bibby SMP 3 micro-melting point apparatus, were used without correction. Optical rotation values were determined with a Jasco DIP-1000 digital polarimeter. UV and IR spectra were obtained with a Hitachi U-2000 spectrometer and a Jasco FT/IR-550 spectrometer, respectively. ${ }^{1} \mathrm{H}-$ and ${ }^{13} \mathrm{C}-\mathrm{NMR}$ spectra were measured with a Jeol JNM- $\alpha 400$ (400 and 100 MHz, respectively), using TMS as an internal standard. FAB mass spectra were obtained with a Jeol JMS-700 spectrometer using glycerol as a matrix, and ESI mass spectra were taken with a Thermo Electron LCQ spectrometer.

Extraction and Isolation Dried propolis collected on Jeju island in Korea (40 g) was extracted with $1200 \mathrm{ml}$ of ethanol at room temperature for 3 days, and then concentrated under reduced pressure to give a crude extract. This extract was subjected to silica gel column chromatography $(50 \times 450 \mathrm{~mm}$ i.d.), using a hexane/EtOAc gradient system for elution. The fractions eluted with hexane-EtOAc $=2: 1$ and 1: 2 were rechromatographed by preparative HPLC in a $20 \times 250 \mathrm{~mm}$ i.d. ODS column (Shiseido Capcell Pak C18, Tokyo) in $10 \mathrm{ml} \mathrm{CH}_{3} \mathrm{CN}-\mathrm{H}_{2} \mathrm{O}$ (6: 4) to give 1 (90 mg), 2 (49 mg) and 3 (145 mg).

4'-Methoxy-bavachromanol (1) Yellow powder; mp 215 ${ }^{\circ} \mathrm{C}$; UV (EtOH) $\lambda_{\max }(\log \varepsilon) 347$ (4.11) nm; IR $\nu_{\max }$ (nujol) $\mathrm{cm}^{-1}$ : 3420, 2970, 2940, 1680; HRFABMS (high resolution fast atom bombardment mass spectrum) $m / z 355.1573$ (calculated for $\left.\left.\mathrm{C}_{21} \mathrm{H}_{23} \mathrm{O}_{5}, 355.1545[\mathrm{M}+\mathrm{H}]\right]^{+}\right) ;{ }^{1} \mathrm{H}$ - and ${ }^{13} \mathrm{C}-\mathrm{NMR}$ data are shown in Table 1. 
<smiles>COc1ccc(C(=O)/C=C/c2ccc(O)cc2)c2c1CC(O)C(C)(C)O2</smiles>

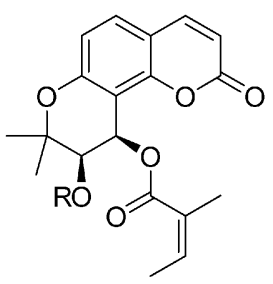

$2 \mathrm{R}=\mathrm{H}$

$4 \mathrm{R}=\mathrm{COCH}_{3}$

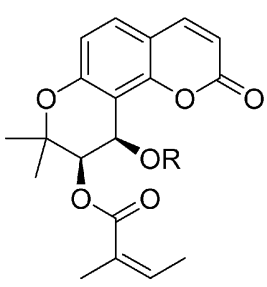

$3 \mathrm{R}=\mathrm{H}$

$5 \mathrm{R}=\mathrm{COCH}_{3}$
Fig. 1. Structures of $4^{\prime}$-methoxy-bavachromanol (1), laserpitin (2) and isolaserpitin (3).

Acetylation of 2 and 3 A crude mixture $(20 \mathrm{mg})$ of 2 and 3 , acetic anhydride $(3 \mathrm{ml})$ and anhydrous pyridine $(3$ $\mathrm{ml}$ ) were kept at room temperature for $1 \mathrm{~h}$. The excess acetic anhydride was decomposed with $\mathrm{MeOH}$, and the solvent was removed under reduced pressure. The acetylated 2 and 3 were purified by preparative HPLC to give the monoacetates $4(10 \mathrm{mg})$ and $5(5 \mathrm{mg})$, respectively.

$3^{\prime}$-acetyl-4'-(2"-methyl-2"-butenoxy) khellactone (4) White amorphous; ESIMS (electrospray ionization mass spectrum) $m / z \quad 409[\mathrm{M}+\mathrm{Na}]^{+} ;{ }^{1} \mathrm{H}-\mathrm{NMR}$ (in acetone- $d_{6}$ ): $\delta$ 1.47 (s, 6H), 1.85 (s, 3H), 1.95 (d, 3H, J=7.2 Hz), 2.06 (s, 3H), 5.33 (d, $1 \mathrm{H}, J=4.8 \mathrm{~Hz}), 6.05$ (q, $1 \mathrm{H}, J=7.2 \mathrm{~Hz}), 6.23(\mathrm{~d}, 1 \mathrm{H}, J=9.6$ $\mathrm{Hz}), 6.59(\mathrm{~d}, 1 \mathrm{H}, J=4.8 \mathrm{~Hz}), 6.86(\mathrm{~d}, 1 \mathrm{H}, J=8.4 \mathrm{~Hz}), 7.62(\mathrm{~d}, 1 \mathrm{H}$, $J=8.4 \mathrm{~Hz}$ ), $7.90(\mathrm{~d}, 1 \mathrm{H}, J=9.6 \mathrm{~Hz}) ;{ }^{13} \mathrm{C}-\mathrm{NMR}$ (in acetone- $d_{6}$ ): 815.7, 20.6, 20.7, 22.3, 25.5, 61.0, 71.2, 78.0, 108.1, 113.5, 113.6, 115.0, 128.6, 130.8, 137.7, 144.7, 155.0, 157.0, 160.0, 167.3, 170.1; $\left.[\alpha]_{\mathrm{D}}^{27}+28.6^{\circ}(c) .75, \mathrm{MeOH}\right)$.

$4^{\prime}$-acetyl-3'-(2"'-methyl-2"-butenoxy) khellactone (5) White amorphous; ESIMS $m / z 409[\mathrm{M}+\mathrm{Na}]^{+} ;{ }^{1} \mathrm{H}-\mathrm{NMR}$ (in acetone- $\left.d_{6}\right): \delta 1.49$ (s, 6H), $1.86(\mathrm{~s}, 3 \mathrm{H}), 1.94(\mathrm{~d}, 3 \mathrm{H}, J=7.2 \mathrm{~Hz}$ ), 2.06 (s, 3H), 5.40 (d, $1 \mathrm{H}, J=4 . \mathrm{Hz}), 6.18$ (q, $1 \mathrm{H}, J=7.2 \mathrm{~Hz}), 6.24$ (d, $1 \mathrm{H}, J=9.6 \mathrm{~Hz}), 6.56(\mathrm{~d}, 1 \mathrm{H}, J=4.8 \mathrm{~Hz}), 6.87(\mathrm{~d}, 1 \mathrm{H}, J=8.4$ $\mathrm{Hz}), 7.61(\mathrm{~d}, 1 \mathrm{H}, J=8.4 \mathrm{~Hz}), 7.91(\mathrm{~d}, 1 \mathrm{H}, J=9.6 \mathrm{~Hz}) ;{ }^{13} \mathrm{C}-\mathrm{NMR}$ (in acetone- $d_{6}$ ): $\delta 15.9,20.6,20.7,23.0,25.1,61.7,70.8,78.4$, $107.9,113.5,113.6,114.9,128.0,130.6,139.8,144.8,155.0,157.5$, $160.1,166.8,170.0 ;[\alpha]_{\mathrm{D}}^{27}-24.3^{\circ}(c \mathrm{c} 0.25, \mathrm{MeOH})$.

Soybean lipoxygenase inhibitory assay Soybean lipoxygenase activity was measured by a spectrophotometric method (Komoda et al., 1995). In the standard assay, $20 \mu 1$ of a sample $\mathrm{MeOH}$ solution and $2 \mathrm{ml}$ of a $0.2 \mathrm{M}$ borate buffer at $\mathrm{pH} 9.0$, were used. In the control test, the same volume of $\mathrm{MeOH}$ was used instead of the sample solution. An enzyme solution ( 1000 units in $25 \mu 1$ of a $0.2 \mathrm{M}$ borate buffer) was then added, and preincubation was carried out for $5 \mathrm{~min}$ at room temperature. Next, $50 \mu 1$ of a linoleic acid solution $(4.18 \mathrm{mM}$ in EtOH) was added, and the increase in absorbance at $234 \mathrm{~nm}$ was recorded. This
Table 1. NMR Data for Compound $1^{a}$.

\begin{tabular}{crll}
\hline Position & $\delta \mathrm{C}$ & & \multicolumn{1}{c}{$\delta \mathrm{H}$} \\
\hline 1 & 128.03 & $\mathrm{C}$ & \\
2 & 130.75 & $\mathrm{CH}$ & $7.55(1 \mathrm{H}, \mathrm{d}), \mathrm{J}=8.0 \mathrm{~Hz}$ \\
3 & 116.76 & $\mathrm{CH}$ & $6.92(1 \mathrm{H}, \mathrm{d}), \mathrm{J}=8.0 \mathrm{~Hz}$ \\
4 & 160.33 & $\mathrm{C}$ & \\
5 & 116.76 & $\mathrm{CH}$ & $6.92(1 \mathrm{H}, \mathrm{d}), \mathrm{J}=8.0 \mathrm{~Hz}$ \\
6 & 130.75 & $\mathrm{CH}$ & $7.55(1 \mathrm{H}, \mathrm{d}), \mathrm{J}=8.0 \mathrm{~Hz}$ \\
$1^{\prime}$ & 123.16 & $\mathrm{C}$ & \\
$2^{\prime}$ & 154.18 & $\mathrm{C}$ & \\
$3^{\prime}$ & 110.18 & $\mathrm{C}$ & \\
$4^{\prime}$ & 161.86 & $\mathrm{C}$ & \\
$5^{\prime}$ & 103.07 & $\mathrm{CH}$ & $6.64(1 \mathrm{H}, \mathrm{d}), \mathrm{J}=8.0 \mathrm{~Hz}$ \\
$6^{\prime}$ & 125.63 & $\mathrm{CH}$ & $7.56(1 \mathrm{H}, \mathrm{d}), \mathrm{J}=8.0 \mathrm{~Hz}$ \\
$4^{\prime \prime}$ & 27.32 & $\mathrm{CH}$ & $2.60(1 \mathrm{H}, \mathrm{dd}), \mathrm{J}=8.8,7.7 \mathrm{~Hz}$ \\
& & & $2.95(1 \mathrm{H}, \mathrm{dd}), \mathrm{J}=8.8,7.2 \mathrm{~Hz}$ \\
$5^{\prime \prime}$ & 68.90 & $\mathrm{CH}$ & $3.85(1 \mathrm{H}, \mathrm{dd}), \mathrm{J}=8.8,7.2 \mathrm{~Hz}$ \\
$6^{\prime \prime}$ & 78.59 & $\mathrm{C}$ & \\
$\alpha$ & 130.65 & $\mathrm{CH}$ & $7.58(1 \mathrm{H}, \mathrm{d}), \mathrm{J}=15.0 \mathrm{~Hz}$ \\
$\beta$ & 141.43 & $\mathrm{CH}$ & $7.57(1 \mathrm{H}, \mathrm{d}), \mathrm{J}=15.0 \mathrm{~Hz}$ \\
$\beta^{\prime}$ & 190.31 & $\mathrm{C}$ & \\
$\mathrm{CH}_{3}$ & 20.95 & $\mathrm{CH}$ & $1.36(3 \mathrm{H}, \mathrm{s})$ \\
$\mathrm{CH}_{3}$ & 25.97 & $\mathrm{CH}$ & $1.43(3 \mathrm{H}, \mathrm{s})$ \\
\hline $\mathrm{OCH}_{3}$ & 56.11 & $\mathrm{CH}{ }_{3}$ & $3.90(3 \mathrm{H}, \mathrm{s})$ \\
\hline
\end{tabular}

${ }^{a}$ Measured in acetone- $d_{6}$ at $400 \mathrm{MHz}$ for ${ }^{1} \mathrm{H}$ and at $100 \mathrm{MHz}$ for ${ }^{13} \mathrm{C}$.

increase in absorbance was compared with that obtained in the control test.

\section{Results and Discussion}

Compound 1 was obtained as a yellow powder. The molecular formula of 1 was determined to be $\mathrm{C}_{21} \mathrm{H}_{22} \mathrm{O}_{5}$ by HRFABMS. The IR spectrum of 1 indicated the presence of hydroxyl and carbonyl functions. The ${ }^{1} \mathrm{H}-\mathrm{NMR}$ spectrum of 1 in acetone- $d_{6}$ gave two sharp singlets at $\delta 1.36$ and 1.43 for geminal dimethyl protons. A triplet at $\delta 3.85$, which was coupled with methylene protons at $\delta 2.60$ and 2.95 , indicated the presence of a methine proton attached to a carbon bearing a secondary hydroxyl group. There were two ortho-coupled doublets at $\delta 6.64$ and 6.92 integrating for one and two protons, respectively. Multiplet signals between $\delta 7.54$ and 7.59 integrating for five protons were also observed. The ${ }^{13} \mathrm{C}$-NMR spectrum of 1 contained 21 carbon signals. The signals in the ${ }^{1} \mathrm{H}$ - and ${ }^{13} \mathrm{C}$-NMR spectra were assigned from the ${ }^{1} \mathrm{H}-{ }^{-1} \mathrm{H}$ COSY, HSQC and HMBC data. In the HMBC spectrum of 1 , correlations supporting the chalcone structure were observed. Figure 2 shows the key HMBC correlations (H to C) for 1 . Based on these results, compound 1 was determined to be $4,5^{\prime \prime}$-dihydroxy-4'-methoxy- $6^{\prime \prime}, 6^{\prime \prime}$-dimethyldihydropyrano-( $\left.2^{\prime \prime}, 3^{\prime \prime}: 2^{\prime}, 3^{\prime}\right)$-chalcone, a new chalcone $4^{\prime}$ methoxy-bavachromanol. However, the configuration of $5^{\prime \prime}$-position is unknown. Bavachromanol, containing the 4'-OH group, has been reported from the seed of Psoralea corylifolia (Suri et al., 1980). 


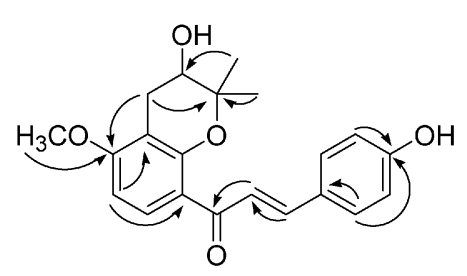

Fig. 2. Key $\mathrm{HMBC}$ correlations ( $\mathrm{H}$ to $\mathrm{C}$ ) for 1.

Compounds 2 and 3 easily interconverted with each other when dissolved in alcoholic solvent. Thus the structure of these compounds was determined by using the acetyl derivatization. Compounds 2 and 3 were stabilized by acetylation for spectroscopic analysis such as MS and NMR by acetylation. By comparison with literature data, 2 and 3 were identified to be laserpitin and isolaserpitin, respectively, which are khellactone derivatives. Laserpitin and isolaserpitin are reported to have been isolated from the plants, Musineon divaricatum (Swager et al., 1985) and Angelica keiskei (Akihisa et al., 2003). However, this is the first report of the isolation of 2 and 3 from propolis.

Compound 1 was evaluated for their soybean lipoxygenase inhibitory activity. The results showed that 1 had strong enzyme-inhibitory activity with $\mathrm{IC}_{50}$ values of $14.6 \mu \mathrm{M}$. The $\mathrm{IC}_{50}$ value of the well-known lipoxygenase inhibitor, kojic acid, was $19.5 \mu \mathrm{M}$ in the present assay.

Lipid peroxidation is one of the major factors in deterioration during the storage and processing of foods. The results presented here show that compound 1 was a potent inhibition of lipoxygenase. This result suggests that propolis collected on Jeju Island may be used as a source for antioxidant food additives.

Acknowledgements This work was supported by a grant-aid for scientific research from the Ministry of Education, Culture, Sports, Science, and Technology of the Japanese government.

\section{References}

Ahn, M.-R., Kumazawa, S., Hamasaka, T., Bang, K.-S. and Nakayama, T. (2004). Antioxidant activity and constituents of propolis collected in various areas of Korea. J. Agric. Food Chem., 52, 7286-7292.

Akihisa, T., Tokuda, H., Ukiya, M., Iizuka, M., Schneider, S., Ogasawara, K., Mukainaka, T., Iwatsuki, K., Suzuki, T. and
Nishino, H. (2003). Chalcones, coumarins, and flavanones from the exudates of Angelica keiskei and their chemopreventive effects. Cancer Lett., 201, 133-137.

Amoros, M., Lurton, E., Boustie, J., Girre, L., Sauvager, F. and Cormier, M. (1994). Comparison of the anti-herpes simplex virus activities of propolis and 3-methylbut-2-enyl caffeate. $J$. Nat. Prod., 64, 235-240.

Bankova, V.S., Castro, S.L.D. and Marcucci, M.C. (2000). Propolis: recent advances in chemistry and plant origin. Apidologie, 31, $3-15$.

Burdock, G.A. (1998). Review of the biological properties and toxicity of bee propolis (propolis). Food Chem. Toxicol., 36, 347363.

Kimoto, T., Aga, M., Hino, K., Koya-Miyata, S., Yamamoto, Y., Micallef, M.J., Hanaya, T., Arai, S., Ikeda, M. and Kurimoto, M. (2001). Apoptosis of human leukemia cells induced by Artepillin $\mathrm{C}$, an active ingredient of Brazilian propolis. Anticancer Res., 21, 221-228.

Komoda, T., Morimitsu, Y., Hirota, H. and Hirota, A. (1995). USF-19 A, a new lipoxygenase inhibitor from Streptomyces sp. Biosci. Biotechnol. Biochem., 59, 924-926.

Kujumgiev, A., Tsvetkova, I., Serkedjieva, Y., Bamkova, V., Christov, R. and Popov, S. (1999). Antibacterial, antifungal and antiviral activity of propolis of different geographic origin. J. Ethnopharmacol., 64, 235-240.

Kumazawa, S., Yoneda, M., Shibata, I., Kanaeda, J., Hamasaka, T. and Nakayama, T. (2003). Direct evidence for the plant origin of Brazilian propolis by the observation of honeybee behavior and phytochemical analysis. Chem. Pharm. Bull., 51, 740-742.

Kumazawa, S., Hamasaka, T. and Nakayama, T. (2004). Antioxidant activity of propolis of various geographic origins. Food Chem., 84, 329-339.

Marcucci, M.C. (1995). Propolis: chemical composition, biological properties and therapeutic activity. Apidologie, 26, 83-99.

Marcucci, M.C. and Bankova, V. (1999). Chemical composition, plant origin and biological activity of Brazilian propolis. Current Topics Phytochem., 2, 115-123.

Suri, J.L., Gupta, G.K., Dhar, K.L. and Atal, C.K. (1980). Bavachromanol: A new chalcone from the seeds of Psoralea corylifolia. Phytochemistry, 19, 336-337.

Swager, T.M. and Cardellina II, J.H. (1985). Coumarins from Musineon divaricatum. Phytochemistry, 24, 805-813.

Tazawa, S., Warashina, T. and Noro, T. (1999). Studies on the constituents of Brazilian propolis II. Chem. Pharm. Bull., 47, 1388-1392.

Tazawa, S., Warashina, T. and Noro, T. (2000). On the chemical evaluation of propolis. Nat. Med. (in Japanese), 54, 306-313.

Wang, L., Mineshita, S., Ga, I., Shigematsu, T. and Matsuno, T. (1993). Antiinflammatory effect of propolis. Jpn. J. Pharmacol. Ter., 24, 223-224. 